\title{
ペルテス病後の股関節痛と外側縁傾斜角
}

\begin{tabular}{|c|c|c|c|c|}
\hline \multicolumn{5}{|c|}{ 久留米大学整形外科 } \\
\hline 百 & 田 & 耕・樋 & 口 & 富士男 \\
\hline 梅 & 田 & 幸三郎・山 & 田 & 康 人 \\
\hline 橋 & 詰 & 弘 - 井 & 上 & 明 \\
\hline
\end{tabular}

\section{A Follow-up Study of Legg-Calve-Perthes Disease-Relationship between hip pain and acetabular roof angle-}

by

\section{Kou Momota, Fujio Higuchi, Kouzaburou Umeda, Yasuto Yamada, Takahiro Hasizume, Akio Inoue}

Department of Orthopaedic Surgery,

Kurume University School of Medicine

A follow-up study of the eighteen hips with previous episode of Legg-Calve-Perthes disease aged over eighteen years old was carried out. There were close relationship between hip pain and acetabular roof angle in X-ray findings. It could be concluded that the acetabular roof angle is an important factor to predict the prognosis of Legg-Calve-Perthes disease.

$$
\text { は じめ に }
$$

ペルテス病後の変形性股関節症への進展は, $20 \%$ 前 後と報告され, 本症の長期的予後は, 比較的に良好と 言われているが, 1985 年, 井上ら ${ }^{5)}$ は, ペルテス病後 の変形性股関節症発現の予後因子として, 臼蓋側の因 子が大切であるとし, 外側縁傾斜角 (以下, ARA と略 す)で判定するのが簡単であると報告している.今回, これに焦点をあて, 当科で取扱った症例につき予後判 定因子を検討したので報告する。

\section{症例}

1983 年から 1988 年の 6 年間に, 当科を受診したペル テス病の既往歴を有する 18 才以上の症例は 18 例であ る. 男性 16 例, 女性 2 例, 受診時年令は, 最低 18 才 から最高 54 才である.これらの症例に対して, 股関節 痛の有無, $\mathrm{X}$ 線像, および治療後の経過について検討 した.

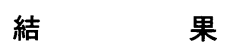

ペルテス病後に, 成人となって股関節痛を訴えたも
のは, 18 例中 15 例 15 関節であり, すべてペルテス病 発症側である (有症状群). あとの 3 例 3 関節には, 股 関節痛はなかった(無症状群)。これら有症状群と無症 状群のペルテス病発症年令および，骨頭変形の程度を 検討すると, 表 1 のごとく, 有症状群では, 平均ペル テス病発症年令は 9 才 3 力, 無症状群は 7 才 6 力月 と, 有症状群の発症年令が高い傾向がみられた。また， 骨頭変形の程度は Catterall の評価 ${ }^{2}$ にしたがい good, fair, poor に分けると, 有症状群では全例 fair と poor に分けることができた。つまり骨頭変形が強く,より 扁平化した骨頭に症状が現れるようである.つぎに, 受診時のペルテス病発症側のX線像を検討すると（表 2 ), 有症状群では, 外側縁傾斜角の良好な ARA(+)

表 1 有症状群と無症状群の検討

\begin{tabular}{r|c|c}
\hline \hline & 有症状群 (15) & 無症状群 (3) \\
\hline 平均ペルテス病発症年令 & 9才 3 カ月 & 7才 6 月月 \\
\hline Catterallの (good) & 0 & 1 \\
骨頭変形評価 (fair) & 9 & 2 \\
(poor) & 6 & 0 \\
\hline
\end{tabular}


表 2 有症状群と無症状群のX線像の検討

\begin{tabular}{cc|c|c}
\hline \hline & & 有症状群 (15) & 無症状群 (3) \\
\hline \multirow{4}{*}{ ARA } & $(+)$ & 0 & 3 \\
& $($ ( ) & 2 & 0 \\
& $(-)$ & 13 & 0 \\
\hline \multirow{2}{*}{ AHI } & 平 均 值 & 60.5 & $72.0^{*}$ \\
& 標準偏差 & 8.9 & 4.0 \\
\hline \multirow{2}{*}{ Sharp角 } & 平 均 值 & 46.2 & $40.0^{* *}$ \\
& 標準偏差 & 4.5 & 0 \\
\hline
\end{tabular}

$* \mathrm{p}<0.05 \quad * * \mathrm{p}<0.01$

表 3 手術例 $\mathrm{X}$ 線像の検討

\begin{tabular}{|c|c|c|c|}
\hline & & 術前 & 術 \\
\hline ARA & $\begin{array}{l}(+) \\
(0) \\
(-)\end{array}$ & $\begin{array}{l}0 \\
1 \\
8\end{array}$ & $\begin{array}{l}8 \\
1 \\
0\end{array}$ \\
\hline $\mathrm{AHI}$ & $\begin{array}{l}\text { 平 均 值 } \\
\text { 標準偏差 }\end{array}$ & $\begin{array}{r}57.6 \\
8.9\end{array}$ & $\begin{array}{c}77.1^{*} \\
7.8\end{array}$ \\
\hline Sharp角 & $\begin{array}{l}\text { 平 均 値 } \\
\text { 標準偏差 }\end{array}$ & $\begin{array}{r}48.1 \\
3.8\end{array}$ & $\begin{array}{l}39.8^{* *} \\
3.2\end{array}$ \\
\hline
\end{tabular}

$* \mathrm{p}<0.01 \quad * * \mathrm{p}<0.01$

はなく, ARA (O)が 2 例, ARA (一) が 13 例であっ

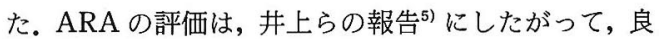
好なものを(十)，不良なものを(一)，その中間に位 置するものを（0）の符合で表した。平均の臼蓋骨頭 被覆率（以下，AHI と略す）は $60.5 \%$, Sharp 角は $46.2^{\circ}$ であった。無症状群では, ARA $(+)$ は 3 例であ り ARA の不良な例はなかった. AHI は平均 $72.0 \%$, Sharp 角は平均 $40.0^{\circ}$ であり, 有症状群と比較すると統 計学的に有意の差が認められた。

つぎに，股関節痛を訴えた 15 例の現在の状況は，9 例に手術施行，2 例が手術予定，3例が外来にて経過 観察中である。残り 1 例は, 手術の適応があったが初 診時以降, 来院していない.

手術した 9 例のうちわけは，5例がChiari 骨盤骨切 り術（大腿骨外反骨切り術併用 1 例, 大腿骨内反骨切 り術併用 1 例)，4 例が大腿骨外反骨切り術と兒蓋形成 術の併用であった。術後観察期間は 9 力月から 10 年, 平均 3 年 8 カ月である。術後, 股関節痛がとれたもの 6 例, 術前と比べると良いが, 長く歩いたり, 寒い時 に股関節痛が出現するもの 3 例と, 全例改善がみられ た。この 9 例の術前と術後経過観察時の X線像を比較

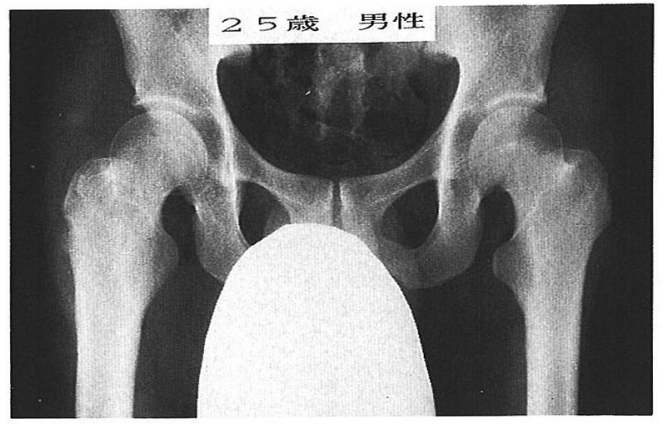

図1右ペルテス病後, ARA 良好である.

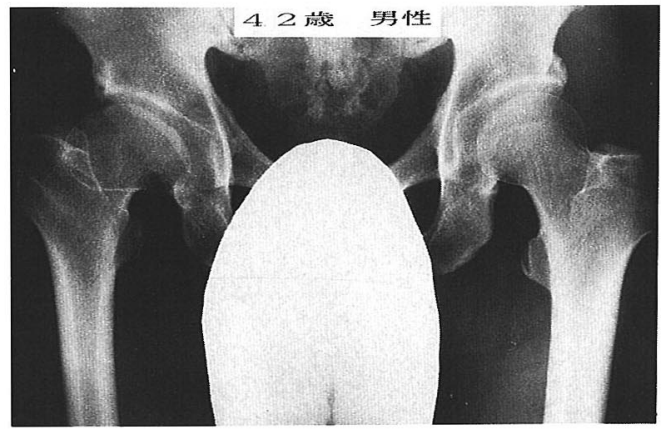

図 2 右ペルラ゙ス病後, 扁平股を認めるが, ARA 良好 である。

すると, 表 3 のごとく, 術前, ARA (一) 8 例, ARA (0) 1 例, $\mathrm{AHI}$ 平均 $57.6 \%$, Sharp 角平均 $48.1^{\circ}$ で あったものが, 術後, ARA (+) 8例, ARA (0) 1 例, $\mathrm{AHI}$ 平均 $77.1 \%$, Sharp 角平均 $39.8^{\circ}$ と改善して いた。

\section{症 例 供 覧}

症例 $1: 25$ 才，男性（図 1)

6 才の頃, 跛行が出現し, 右ペルテス病の診断にて， 大腿骨内反骨切り術を施行された。以後, 股関節痛は なかったが，25才の頃，右膝関節痛を訴えて当科を受 診した。股関節 X線像は, ARA は左右とも $(+), \mathrm{AHI}$ は, 右 $75.5 \%$, 左 $78.8 \%$, Sharp 角は左右とも $40^{\circ}$ で あり若干の臼蓋形成不全を認めるが，膝関節痛は薬物 治療にて軽快し，股関節痛もなく良好な状態である。

症例 $2: 42$ 才，男性（図 2)

8 才時に右ペルテス病を指摘されたが，放置した。 その後，跛行はあったが股関節痛はなかった。 42 才時 に腰痛にて当科を受診する。脚長差 $3 \mathrm{~cm}$ のため,わず 


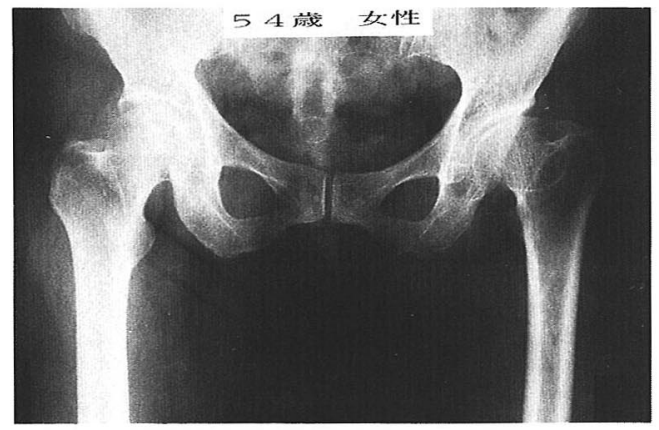

図 3 左ペルテス病後, 扁平股を認め, ARA 不良であ る.

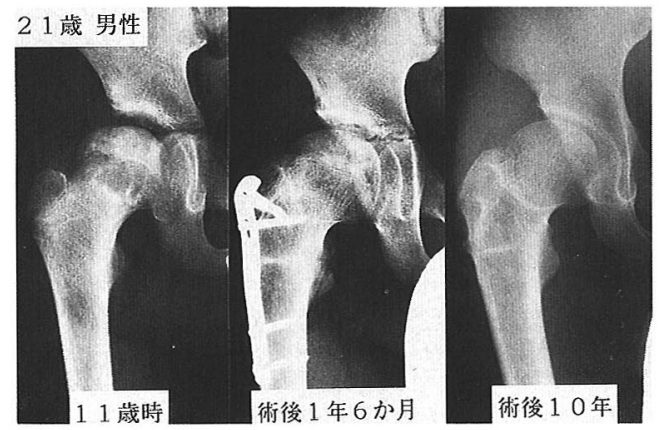

図 4 ペルテス病治療終了時と成人後のX線像で変化 ない.

かな跛行を認めるが，股関節痛は訴えなかった，X線 像では，右側はペルテス病の遺残変形である巨大扁平 股を認め, AHI は $65.5 \%$ と不良であるが, ARA は(+) である、関節裂隙の状態も良好であり，今のところ， とくに問題ないと思われる。 症例 $3: 54$ 才，女性（図 3)

8 才の頃, 跛行が出現し, 装具を 1 年間装着した。 その後，時々，左股関節痛を訴えていたが，最近にな つて痛みが増強したため，当科を受診した。疼痛は中 等度で，軽度の可動制限を認めた．X線像では，ARA は (一), AHI は $60.7 \%$ と不良であり, 将来, 増悪し てくると思われる。Chiari 骨盤骨切り術の予定である。 症例 $4: 21$ 才，男性（図 4)

11 才時に, 右ペルテス病の診断で, 当科にて大腿骨 内反骨切り術を受けている。術後 1 年 6 力月, ペルテ ス病治療終了時のX線像は ARA は(一), AHI $62 \%$ \% あった。術後, 経過良好であったが, 術後 10 年, 21 才 時に右股関節痛が出現し当科を受診した。軽度の可動

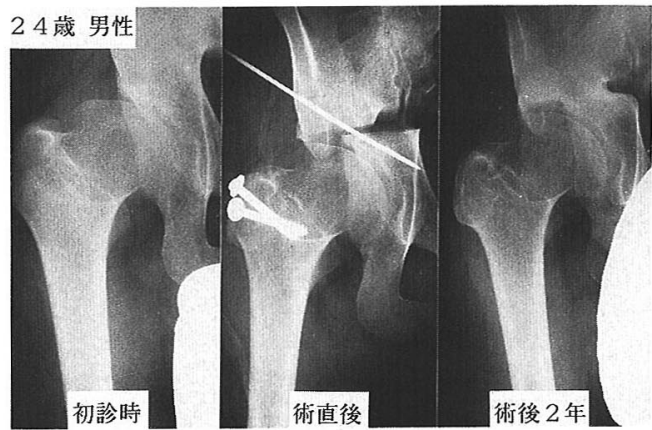

図 5 術後，ARA の改善をみる。

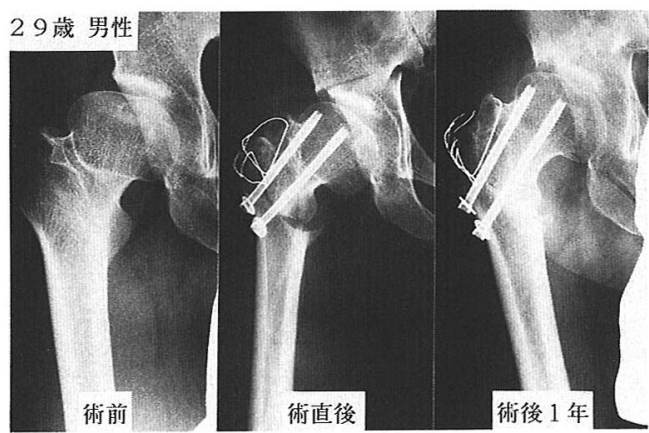

図 6 術後，ワイヤーの折損を認めるが，関節の状態 は良好である。

制限を認め, X線像では, ARA (-), AHI $63 \%$, Sharp 角 $50^{\circ}$ という臼蓋形成不全であった. また,ペルテス病 治療終了時のX線像とそれほど変化していない.現在, 経過観察中である。

症例 $5: 24$ 才，男性（図 5)

4 才時に，右ペルテス病の診断にて，ギプス治療を 受けている.その後, とくに症状はなかったが, 24 才 時に右股関節痛が出現し, 当科を受診した。受診時 $\mathrm{X}$ 線像は，ARA (-)，AHI $50 \%$, Sharp 角 $55^{\circ}$ であっ た.Chiari 骨盤骨切り術施行し, 術後 2 年で股関節痛 は軽減している。X線像でも ARA(+), AHI $81.4 \%$, Sharp 角 $35^{\circ}$ と改善した。

症例 $6: 29$ 才, 男性（図 6)

11 才時に, 右ペルテス病の診断にて，3 年問装具を 装着した。その後, 症状はなかったが, 29 才時に右股 関節痛出現し, 当科を受診した。股関節痛が強く, 中 等度の可動制限を認め, X線像では, ARA (一), AHI 59.4\%, Sharp 角 $50^{\circ}$ であった. Chiari 骨盤骨切 り術と大腿骨内反骨切り術の併用を行い, 術後 1 年の 
現在，大転子部に圧痛を認めるものの，術前の股関節 痛は軽減している。術後 1 年の $X$ 線像でも, 大転子部 固定のワイヤーの折損を認めるが, ARA (+), AHI 74.5 $\%$, Sharp 角 $45^{\circ}$ と改善している.

\section{考察}

1985 年, 井上ら ${ }^{5}$ はペルテス病の長期的予後とその 予後因子について，骨頭の扁平化あるいは巨大化，臼 蓋外側緑の急峻化，臼蓋の不十分な骨頭被覆が，股関 節症の進展に関連しており,この変形はペルテス病治 療終了後より遺残したものであると報告した。また， 予後因子として ARA が,もっとも重要であるとも述べ ている，今回のわれわれの検討でも，有症状群と無症 状群では ARA, AHI, Sharp 角で有意の差が認められ た。 また, 手術例においても, 術後, 症状の改善とと もに, ARA, AHI, Sharp 角は改善している.しかし, 一般的に AHI の正常值は $80 \%$ 以上，Sharp 角は $42^{\circ}$ 以下 ${ }^{3)}$ ということ,および表 2,3 の結果から考えてみ ると,股関節痛の有無と ARA との関連性が強いことが 考えられる。 また, 症例 4 のように, ペルテス病治療 終了時の変形がそのまま成人しても残っていることよ り, ペルステ病治療終了時に ARA が(一)であれば骨 頭の変形や $\mathrm{AHI}$ など, その他の因子の程度にもよるが, 将来, 股関節症に進展する危険性があると考えられる。 ARA (-) つまり, 臼蓋外側縁の急峻化はペルテス病 経過中における巨大骨頭の出現によって, 臼蓋外側縁 の骨端核が障害を受けて生じると考えられる。このよ うにして生じた臼蓋外側縁の急峻化は成人になっても 遺残する. Bombelli ${ }^{11}$ は寛骨臼のある程度以上の傾斜 によって, 骨頭を外上方に移動させる分力 $\mathrm{S}$ の存在を

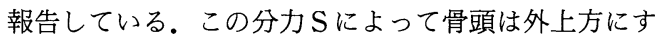
べり, 荷重面積が狭くなり股関節症に進展していくと 考えられる.

井上ら ${ }^{5)}$, 水品 ${ }^{4)}$ は股関節症発症の因子の 1 つにぺ ルテス病発症年令をあげており, 高令発症例（井上ら は 8 才以上, 水品らは 10 才以上) に股関節症発症が多 いと報告している.われわれの症例でも, 統計学的に 有意の差はなかったが, 有症状群において発症年令が 高い傾向がみられた。
治療に関しては, 今回の手術例の検討から, 関節面 の適合性と荷重面積の増大を計ることは当然であるが, それ以上に ARA を(十) とすることが重要であると思 われ，この条件をみたす方法としては，Chiari 骨盤骨 切り術が最適であろう. 最近, ペルテス病後の変形に 対する，この手術の遠隔成績が報告6)されているが，そ れによると長期にわたり好結果をもたらすようである.

\section{ま と め}

1. ペルテス病の既往歴を有する 18 才以上の 18 例 の症例に対して, 股関節痛の有無, X線像, および治 療後の経過について検討した。

2. 股関節痛の有無と ARA の関連性が強く認めら れた.

3. ペルテス病治療終了時の変形, とくに ARA が不 良な症例は将来, 股関節症に進展する危険性があると 思われた。

4. 股関節症の治療に当たっては, ARA の改善が重 要であると考えられる。

\section{参 考 文 献}

1) Bombeli, R.: Osteoarthritis of the hip. SpringerVerlag, Berlin, 20-21, 1976.

2) Catterall, A.: The natural history of Perthes' disease. ibid. 53-B : 37-53, 1971.

3）伊藤鉄夫; 股関節外科学. 金芳堂, 1983.

4）水品彰彦·他：Pertes 病の遠隔成績. 整形外科, 34 : 909-914, 1983.

5）西塔 進・他：Pertes 病の長期的予後とその予後因 子. 整形外科, $36: 137-144,1985$.

6) Zlatic, M. et al. : Late results of Chiari's pelvic osteotomy. International Orthopaedics, $12:$ 149-154, 1988.

質 問 琉球大学 仲宗根 聡

ARA マイナス例の痛みの原因は何だとお考えでしょ うか。

解 答留米大学 百田 耕

ARA (一) になれば骨頭の側方化が起り, 荷重面積 の減少により, 疼痛がでてくると思います. 